\title{
Wireless Networks in industrial environments: State of the art and Issues
}

\author{
Xavier Carcelle, Tuan Dang, Catherine Devic \\ EDF Research\&Development \\ 6 , quai Watier - BP 49 \\ 78401 Chatou Cedex, France \\ \{xavier.carcelle, tuan.dang, catherine.devic\}@edf.fr
}

\begin{abstract}
Wireless is everywhere nowadays and WLAN (i.e. 802.11 standard family) has became used by almost any communications devices in the mass market.

The recent achievements in the fields of modulation techniques, such as Spread Spectrum, coding methods, such as Turbocodes, CDMA2000, and frequencies allocation methods, such as OFDM and Frequency Hopping, has pushed the growing uses of reliable and low-cost wireless technologies. Among them the last standards are: IEEE 802.11 family (i.e. WiFi), HyperLAN and HyperLAN2, IEEE 802.15 (i.e. WPAN), IEEE 802.16 (i.e. WiMAX)...

However, the industrial environments are not taken into consideration in the design of those standards, because its harsh constraints has specific characteristics (reliability, interferences with existing equipments, multi-path propagation, low-power consumption, real-time reconfiguration, security...) that need specific requirements and eventually standards.

This paper will intent to give an overview of the wireless technologies and discusses the current and future possible technologies for the uses in the industrial environments (power plants and stations, factories, industrial buildings, automotive...). Our current works showed us that there is no perfect technology by it-self but the best trade-off solution is a hybrid architecture combining the right wired and wireless technologies.
\end{abstract}

Please use the following format when citing this chapter:

Carcelle, X., Dang, T., Devic, C., 2006, in International Federation for Information Processing (IFIP), Volume 212, Ad-Hoc Networking, ed. Al Agha, K., (Boston: Springer), pp. 141-156. 


\section{Introduction}

The last past years have been intense in terms of development of wireless standards and wireless applications. Those applications are going from mass market domestic uses including Internet access to industrial usage in the field of wireless sensors networks, wireless interconnection between computer based control devices (DCS, PLC...) and industrial asset management based on pervasive networks indoor or outdoor.

These emerging wireless technologies can give benefits in cost-reduction, and reliability in industrial applications as well as opportunities in improving operational performance. But there is still work in progress to achieve usable technologies which meet industrial requirements. Firstly we will present an overview of the current and future wireless technologies from a standardization point of view. Secondly we will analyze the work to be done in the design and implementation in the industrial environments, such as in the utilities installations (power plants, sub-stations, factories). Finally we will present our current experimentations and future works within hybrid technology networking fields.

\section{Overview of wireless communication technologies}

\subsection{Taxonomy and technical overview}

Wireless networking technologies can be divided into three main classes (see Fig). Each class addresses specific requirements and purposes in point-to-point and point-to-multipoint communication.

WPAN addresses Personal Area Network in which most of the time, point-topoint communications are involved. However, point-to-multipoint communications are possible with wireless networks protocols such as PicoNET (based on Bluetooth) or ZigBee (based on IEEE 802.15.4b). The range performances are typically from 1 meter to a few dozens meters. The WPAN are designed for low data rate (usually 100-200 kbps). This family gather the following technologies: ZigBee, Bluetooth and UWB.

WLAN addresses Wireless Local Area Networks where the main uses are interconnecting high data rate applications (Multimedia streaming, files sharing...), building easy-to-deploy HotSpot-like networks and lately Ad-Hoc enabled networks such as Mesh Networks. The range performances are typically from a few dozens meters indoor to a few hundred meters outdoor. The WLAN are designed for high data rate (usually 1 to $20 \mathrm{Mbps}$ ). This family is composed with WiFi and DECT..

Finally WWAN addresses Wireless Wide Area Networks which are mainly focused for long-distance point-to-point high data rate connections. They are designed to link plant sites networks all together with date rate ranging typically over 10Mbps with distance performances over few hundred meters. This long-distance family gathers: WiMAN, WiMAX and GSM. 


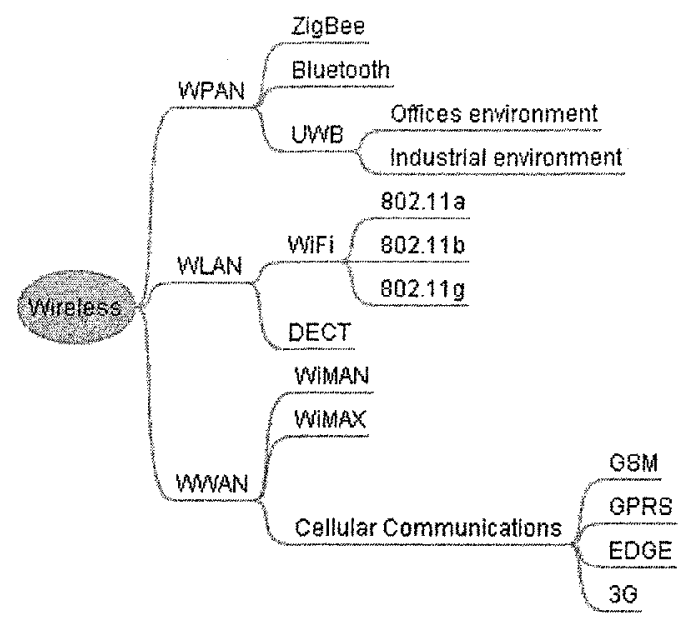

Fig.1. Wireless technologies taxonomy

From a more technical point of view, wireless networks use a lot of underlying mobile communications technologies benefiting from digital signal transmission researches. The following tables present the technical characteristics of the different wireless standards with their respective frequencies and modulation issues. In term of frequency issues, the chapter III will cover the different regulations and the coexistence problems between each wireless technology. It intents to present a brief guideline that may help to make the right choice in industrial applications.

In digital mobile communications systems, the modulation and the multiple access methods are important characteristics that has influence on the efficiency of the channel in terms of: data rate, robustness and power consumption. IEEE describes the robustness [1] as the degree to which a system or component can function correctly in the presence of invalid inputs or stressful environment conditions. Robustness can also be achieved using MIMO systems. In communication theory, MIMO refers to radio links with multiple antennas at the transmitter and the receiver side. Given multiple antennas, the spatial dimension can be exploited to improve the performance of the wireless link. The performance is often measured as the average bit rate (bit/s) the wireless link can provide or as the average bit error rate (BER). Which one has most importance depends on the application. 
Most of digital transmission system uses advanced channel coding technique to prevent errors in the transmission and to correct them in the receiver when they happen. Below (see

Fig) is an example [2] of the encoding method for OFDM:

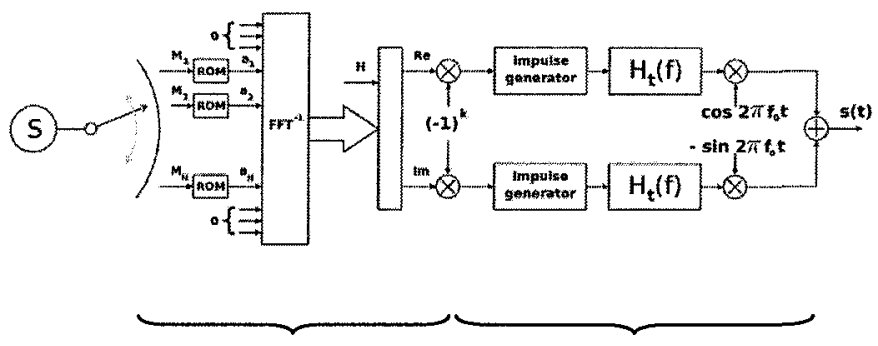

$\begin{array}{lcc}\text { Data } & \text { Channel } & \text { n-QAM or PSK } \\ \text { input } & \text { coding } & \text { Modulation }\end{array}$

Fig.2. OFDM encoder

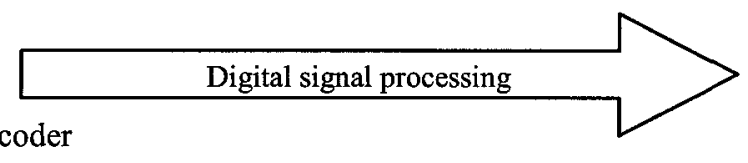

OFDM uses the principle of multi-carrier transmission technique that converts a serial high-rate data stream onto multiple parallel low-rate sub-streams. Each substream is modulated on another sub-carrier. Below is an example of multi-carrier modulation with four sub-channels [3].

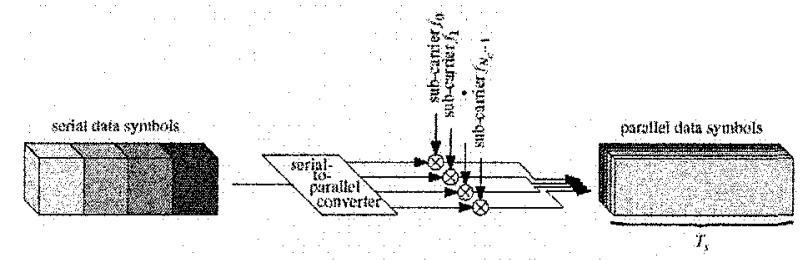

Fig.3. Example of multi-carrier modulation

In Spread Spectrum communication, the baseband signal bandwidth is intentionally spread over a larger bandwidth by injecting a higher-frequency signal. So, energy used in transmitting the signal is spread over a wider bandwidth, and appears as noise. Different Spread Spectrum techniques use different manners of injecting Pseudo Noise sequence (code) to distribute the power of the baseband signal. Below is an illustration of Direct Sequence Spread Spectrum technique [4]. 


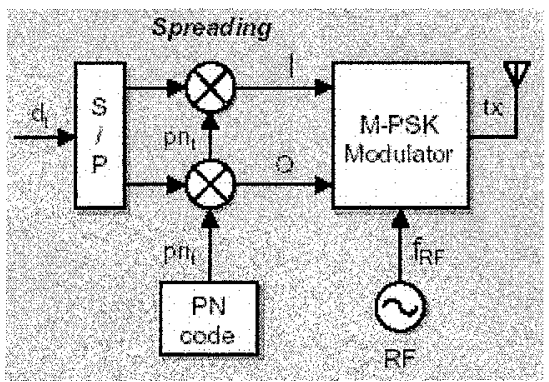

Fig.4. Typical DSSS circuit

Following the standardized OSI model for wireless protocols, the physical (PHY) and the medium access (MAC) layers can be seen as below:

Table 1.. PHY and MAC layers for wireless protocols

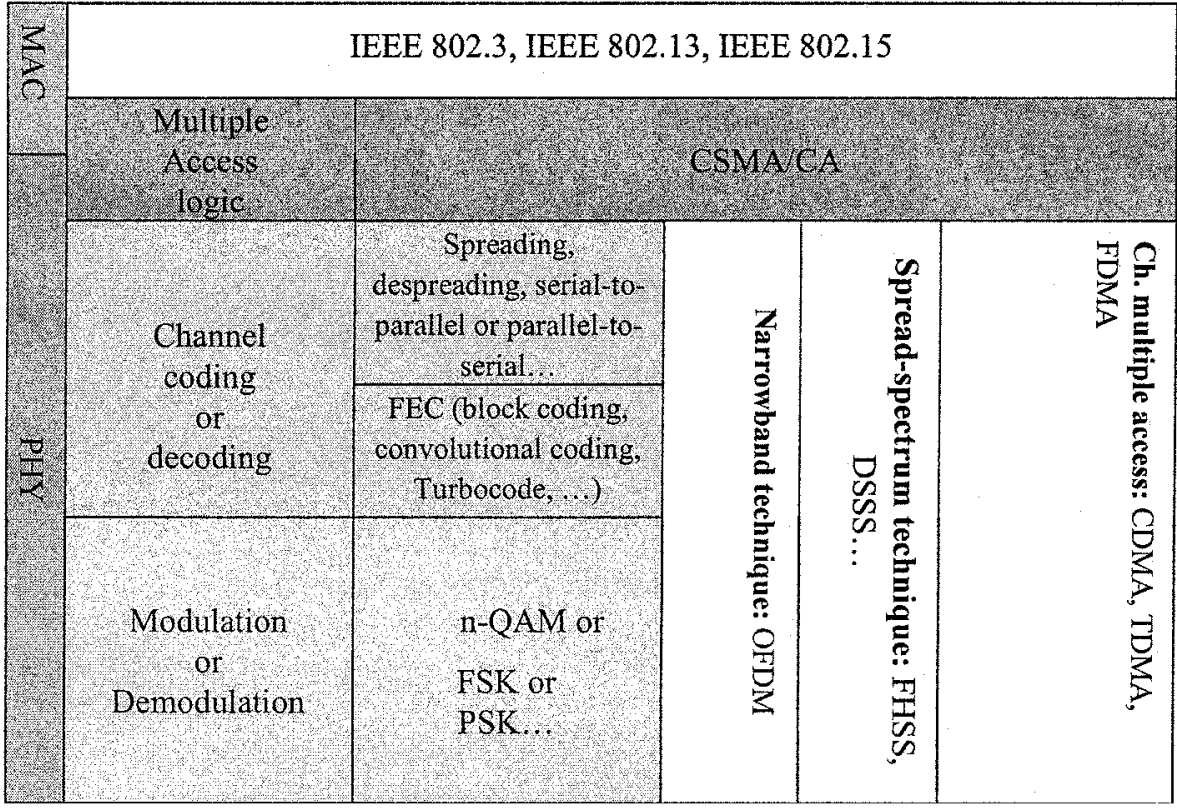

Each digital signal transmission technique has its own advantages and drawbacks. Following is the comparison of the different Multi-Carrier narrowband Transmission and Spread spectrum Techniques: 
Table 2. Comparison of different digital signal transmission techniques

\begin{tabular}{|c|c|c|}
\hline $\begin{array}{l}\text { Transmission } \\
\text { Techinque }\end{array}$ & Avantages. & Drawbacks \\
\hline $\begin{array}{l}\text { FHSS } \\
\text { (Bluetooth, } \\
\text { DECT) }\end{array}$ & $\begin{array}{l}\text { - } \text { robust to interference } \\
\text { - strong with jamming }\end{array}$ & $\begin{array}{l}\text { - limited data rate } \\
\text { - higher power consumption }\end{array}$ \\
\hline $\begin{array}{c}\text { DSSS } \\
\text { (IEEE 802.11b, } \\
\text { ZigBee, GSM) }\end{array}$ & $\begin{array}{l}\text { - support variable data rates } \\
\text { - resistance to multi-path } \\
\text { - resistant to narrow-band } \\
\text { interferences }\end{array}$ & $\begin{array}{l}\text { - sensitive to jamming } \\
\text { limited number of same-cell access } \\
\text { points }\end{array}$ \\
\hline $\begin{array}{c}\text { OFDM } \\
(\text { IEEE } 802.11 \mathrm{~g}, \\
\text { IEEE 802.11a) }\end{array}$ & $\begin{array}{l}\text { Resistance to } \\
\text { - link dispersion } \\
\text { - multi-path } \\
\text { - frequency interference } \\
\text { - burst noise }\end{array}$ & $\begin{array}{l}\text { - higher power consumption } \\
\text { - higher CPU needs }\end{array}$ \\
\hline
\end{tabular}

In the following paragraphs, we will analyse the characteristics of each class of wireless networking technologies:

\subsection{WPAN (Wireless Personal Area Networks)}

WPAN technologies are being quite heavily used these past years in the mass market industry but a very few in the industrial environment. The coming years will see a great spread out of these technologies in the factories and the industry in general. For instance the IEEE 802.15.4 working group is leading the technology standardization for such technologies matching the needs and the requirements. 
Table 3. WPAN technologies

\begin{tabular}{|c|c|c|c|c|}
\hline $\begin{array}{l}\text { Wireless } \\
\text { technology }\end{array}$ & 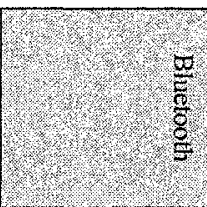 & 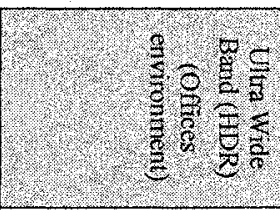 & 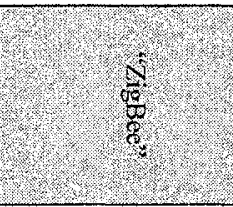 & 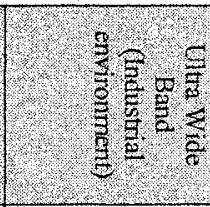 \\
\hline IEEE Standards & 802.15 .1 & 802.15 .3 (WG a) & $\begin{array}{l}802.15 .4 \\
(\mathrm{WG} \mathrm{b})\end{array}$ & $802.15 .4(\mathrm{WG} \mathrm{a})$ \\
\hline Peak data rate & $723.2 \mathrm{kbps}$ & $480 \mathrm{Mbps}$ & $\begin{array}{l}\text { - } 20 \mathrm{kbps}(868 \\
\mathrm{MHz}) \\
\text { - } 40 \mathrm{kbps}(915 \\
\mathrm{MHz}) \\
\text { - } 250 \mathrm{kbps}(2.4 \\
\mathrm{GHz})\end{array}$ & $1 \mathrm{Mbps}$ \\
\hline Frequency range & $2402-2480 \mathrm{MHz}$ & $3.1-4.8 \mathrm{GHz}$ & $\begin{array}{ll}\text { - } & 2.4-2.4835 \mathrm{MHz} \\
\text { - } & 902-928 \mathrm{MHz} \\
& \text { (US) } \\
\text { - } & 868.3 \mathrm{MHz}(\mathrm{Eu})\end{array}$ & $5.9-10.6 \mathrm{GHz}$ \\
\hline Channel bandwidth & $1 \mathrm{MHz}$ & $\begin{array}{l}1.368 \mathrm{GHz} \text { or } \\
2.736 \mathrm{GHz} \text { or } \\
528 \mathrm{MHz}\end{array}$ & $5 \mathrm{MHz}$ & $500 \mathrm{MHz}$ \\
\hline Number of channels & 79 & 2 or 13 & $\begin{array}{l}1(868 \mathrm{MHz}) \\
10(915 \mathrm{MHz}) \\
16(2.4 \mathrm{GHz})\end{array}$ & \\
\hline Multiple access & $\begin{array}{l}\text { TDMA } \\
\text { or } \\
\text { CDMA }\end{array}$ & $\begin{array}{l}\text { Ternary CDMA } \\
\text { or } \\
\text { TFI-OFDM }\end{array}$ & $\begin{array}{l}\text { CSMAVCA with } \\
\text { FDMA and TDMA }\end{array}$ & Impulse Radio \\
\hline Modulation & GFSK & $\begin{array}{l}\text { - BPSK/QPSK (DS- } \\
\text { SS UWB) } \\
\text { - QPSK(MB-OFDM) }\end{array}$ & $\begin{array}{l}\text { - } \text { BPSK (868/915 } \\
\text { MHz) } \\
\text { - OQPSK } \\
(2.4 \mathrm{GHz})\end{array}$ & $\begin{array}{l}\text { TH-PPM } \\
\text { TH-A-PAM }\end{array}$ \\
\hline Power-consumption & +++ & ++ & + & + \\
\hline Range performance & $t$ & + & + & $t$ \\
\hline $\begin{array}{l}\text { Localization } \\
\text { performance }\end{array}$ & + & +1 & + & $4+$ \\
\hline Security & + & $+1+$ & +++ & +4 \\
\hline
\end{tabular}

\subsection{WLAN (Wireless Local Area Networks)}

WLAN technologies headed a huge development these pasts years with main applications such as Private LAN (Local Area Networks) and Public Internet HotSpots where the WiFi technology is now embedded in any electronic device as one 
of the main features. DECT has been also extremely used in-the-homes and is now used in industrial environment for voice and data over the private phone system. For wide industrial environment, such as big factories, storage areas, docks or power plants, DECT might be a good to have a reliable, robust wireless private phone system but also add to this system data communications and emergency alarms using the worldwide ISM bands. The backbone linking the DECT base stations is usually wired.

Table 4. WLAN technologies

\begin{tabular}{|c|c|c|c|c|}
\hline $\begin{array}{c}\text { Wirelest } \\
\text { comm } \\
\text { tecinelog y }\end{array}$ & 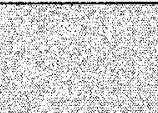 & 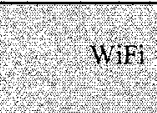 & 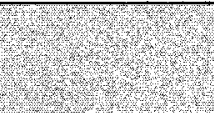 & BECT \\
\hline Standards & $\begin{array}{l}\text { IEEE } \\
802.11 \mathrm{a}\end{array}$ & $\begin{array}{l}\text { IEEE } \\
802.11 \mathrm{~b}\end{array}$ & $\begin{array}{l}\text { IEEE } \\
802.11 \mathrm{~g}\end{array}$ & ETSI \\
\hline Peak data rate & $54 \mathrm{Mbps}$ & $11 \mathrm{Mbps}$ & $54 \mathrm{Mbps}$ & $100 \mathrm{kbps}$ \\
\hline Frequency range & $\begin{array}{ll} & 5.15-5.35 \\
& \mathrm{GHz}(\mathrm{US}) \\
& 5.470- \\
5.725 \\
\mathrm{GHz}(\mathrm{Eu}) \\
-5.725- \\
5.825 \\
\mathrm{GHz} \\
\text { (US/Chin } \\
\text { a) }\end{array}$ & 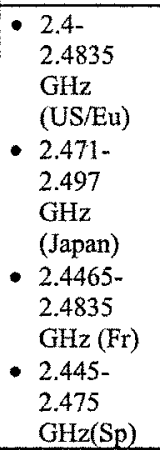 & $2.4-2.4835 \mathrm{GHz}$ & $\begin{array}{l}1880-1900 \mathrm{MHz} \\
\text { (Europe) } \\
1880-1990 \mathrm{MHz} \\
\text { (Worldwide) }\end{array}$ \\
\hline Channel bandwidth & $20 \mathrm{MHz}$ & $20 \mathrm{MHz}$ & $20 \mathrm{MHz}$ & $1.728 \mathrm{MHz}$ \\
\hline Number of channels & 12 & $\begin{array}{l}3 \text { (non } \\
\text { overlapping) }\end{array}$ & 3 (on overlapping) & 10 (12 users per channel) \\
\hline Multiple access & $\mathrm{CSMA} / \mathrm{CA}$ & $\overline{\mathrm{CSMA} / \mathrm{CA}}$ & $\mathrm{CSMA} / \mathrm{CA}$ & $\begin{array}{l}\text { FDMA } \\
\text { TDMA }\end{array}$ \\
\hline Modulation & $\begin{array}{l}\text { BPSK,QP } \\
\text { SK } \\
\text { 16QAM, } \\
\text { 64QAM }\end{array}$ & $\begin{array}{l}\text { - BPSK,DQ } \\
\text { PSK } \\
\text { (Header) } \\
\text { - BPSK,QP } \\
\text { SK(Paylo } \\
\text { ad) } \\
\text { CCK, } \\
\text { PBCC }\end{array}$ & $\begin{array}{l}\text { - BPQK, QPSK, } \\
\text { - 16-64QAM }\end{array}$ & GFSK \\
\hline Power-consumption & + & ++ & + & + \\
\hline Range performance & $4+$ & ++ & +4 & $4+$ \\
\hline Security & +4 & +4 & + & +4 \\
\hline
\end{tabular}




\subsection{WWAN (Wireless Wide Area Networks)}

WWAN technologies is used mainly for two applications nowadays is cellular phone communications and wide range IP-networks such as inter-cities point to point links. The WiMAN technology for instance is high-data rate with range performances up-to several kilometers and no mobility. Whereas the cellular communications for data transfer are usually low-to-fair data rate with complete mobility in the covered areas with GPRS services. From an industrial point of view, the two cases can be found as applications. A far remote power plant can be connected to the corporate backbone using a long-distance IP-based connection like a 802.16 link retrieving data from a sensors. Also a GPRS modem can help to regularly access a remote sensors or enabling a power plant staff to stay connected to the corporate backbone while off-site for a manual metering or a measurement task.

Table 5. WWAN technologies

\begin{tabular}{|c|c|c|c|}
\hline $\begin{array}{l}\text { Wirless } \\
\text { comm. } \\
\text { technology }\end{array}$ & WMAN & Wimax & Cellular Cominunications \\
\hline Standards & $\begin{array}{l}\text { IEEE } \\
802.16\end{array}$ & $\begin{array}{l}\text { IEEE } \\
802.16 \mathrm{a}\end{array}$ & GPRS \\
\hline Peak data rate & $134 \mathrm{Mbps}$ & $\begin{array}{l}\text { a:75Mbps } \\
\text { e:15Mbps }\end{array}$ & $100 \mathrm{kbps}$ \\
\hline Frequency range & $10-66 \mathrm{GHz}$ & $\begin{array}{l}\text { a:2-16GHz } \\
\mathrm{e}: 2-6 \mathrm{GHz}\end{array}$ & GSM bands \\
\hline Channel bandwidth & $\begin{array}{l}20 \mathrm{Mhz} \\
25 \mathrm{MHz} \text { (US) } \\
28 \mathrm{MHz}(\mathrm{Eu})\end{array}$ & $\begin{array}{l}\mathrm{a}: 1.5-20 \mathrm{MHz} \\
\mathrm{e}:>5 \mathrm{MHz}\end{array}$ & usually $1.25 \mathrm{MHz}$ \\
\hline Number of channels & - & $\begin{array}{l}\text { a: } 1.5-20 \mathrm{MHz} \\
\text { e: under definition }\end{array}$ & depends on service \\
\hline Multiple access & TDMA & $\overline{O F D M}$ & CDMA \\
\hline Modulation & QPSK, 16QAM, & $\begin{array}{l}\text { QPSK, 16QAM, } \\
\text { 64QAM }\end{array}$ & QPSK, HPSK \\
\hline Power-consumption & $t++$ & +4 & $\bar{H}$ \\
\hline Range performance & $++t$ & $+t+$ & $T+t$ \\
\hline $\begin{array}{l}\text { Localization } \\
\text { performance }\end{array}$ & $\mp$ & + & +4 \\
\hline Security & $F+t$ & +++ & $t+t$ \\
\hline
\end{tabular}




\section{Frequency regulations and co-existence issues}

\subsection{Frequency regulations issues}

These below tables present a brief overview of the different frequency regulations for the wireless technologies discussed in the previous chapter:

\subsubsection{WPAN}

Table 6. WPAN frequency regulations

\begin{tabular}{|c|c|c|c|c|}
\hline Regron & Bhetooth & $\begin{array}{l}\text { UW B (office } \\
\text { enviromment) }\end{array}$ & $\mathrm{AgBee}$ & $\begin{array}{l}\text { UWB Gndustrat } \\
\text { en Wronnen) }\end{array}$ \\
\hline North America & $\begin{array}{l}\text { ISM } \\
2.4 \\
\mathrm{GHz}\end{array}$ & ISM & $\begin{array}{l}\text { ISM } \\
2.4 \mathrm{GHz}, 916 \mathrm{MHz}\end{array}$ & $\begin{array}{l}\text { FCC } 15.209 \\
\text { and FCC } 2002\end{array}$ \\
\hline Europe & $\begin{array}{l}\mathrm{ISM} \\
2.4 \\
\mathrm{GHz}\end{array}$ & $\begin{array}{l}\mathrm{ECC} / \mathrm{DECC} /(0 \\
6) \mathrm{AA}\end{array}$ & $\begin{array}{l}\text { ISM } \\
2.4 \mathrm{GHz}, 868 \mathrm{MHz}\end{array}$ & $\begin{array}{l}\text { CEPT/ECC/TG3 } \\
41 \mathrm{dBm} / \mathrm{MHz}\end{array}$ \\
\hline Japan & ISM $2.4 \mathrm{GHz}$ & $-41 \mathrm{dBm} / \mathrm{MHz}$ & $\begin{array}{l}\text { ISM } \\
2.4 \mathrm{GHz} \\
868 \mathrm{MHz}\end{array}$ & $-41 \mathrm{dBm} / \mathrm{MHz}$ \\
\hline
\end{tabular}

\subsubsection{WLAN}

Table 7. WLAN frequency regulations

\begin{tabular}{|c|c|c|c|c|}
\hline Region & $802.11 \mathrm{a}$ & 802.116 & 802119 & DECT \\
\hline $\begin{array}{l}\text { North } \\
\text { America }\end{array}$ & ISM & ISM & ISM & ISM \\
\hline Europe & ISM & ISM & ISM & ISM \\
\hline Japan & ISM & ISM & ISM & ISM \\
\hline
\end{tabular}

\subsubsection{WWAN}

Table 8. WWAN frequency regulations

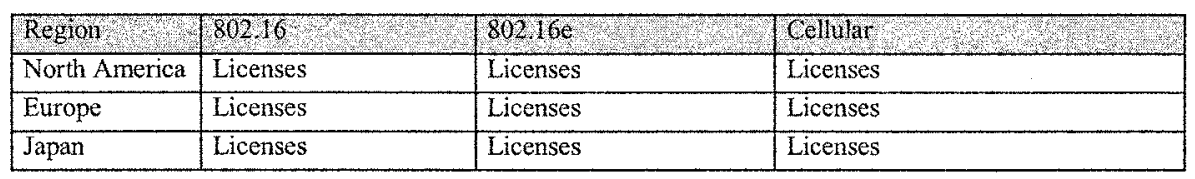




\subsection{Coexistence issues in the $2.4 \mathrm{GHz}$}

The Steinbeis-Transfer Centre [5] has been testing the interference between ZigBee data communications (channel 11 to 26 ) and the other $2.4 \mathrm{GHz}$ technologies. The below table summarizes the main results:

Table 9. Steinbeis-Transfer Centre coexistence tests

\begin{tabular}{|l|c|}
\hline Technology & $\begin{array}{c}\text { Packet loss results } \\
\text { (IEEE } 802.15 \text { frames lost) }\end{array}$ \\
\hline $\begin{array}{l}\mathrm{WiFi} \\
(802.11 \mathrm{~b} / \mathrm{f}=2437 \mathrm{MHz})\end{array}$ & $92 \%$ lost \\
\hline Bluetooth & $10 \%$ lost \\
\hline Microwave & $1 \%$ lost \\
\hline
\end{tabular}

We can see both the $802.11 \mathrm{~b}$ and the 802.15 .4 are DSSS technologies that can interfere a lot between each other compared to other transmission technique in the same band.

Another test of coexistence has been led by the company Crossbow [6] measuring the perturbations of a data communications system with ZigBee technology receiving interferences from Wi-Fi radio frequencies using the $802.11 \mathrm{~b}$ technology and namely the channel 3 at the frequency of $2.422 \mathrm{MHz}$ :

Table 10. Crossbow coexistence tests

\begin{tabular}{|l|l|l|l|l|l|}
\hline $\begin{array}{l}802.15 .4 \\
\text { channel }\end{array}$ & $\begin{array}{l}11 \\
2.405 \mathrm{GHz}\end{array}$ & $\begin{array}{l}14 \\
2.420 \mathrm{GHz}\end{array}$ & $\begin{array}{l}15 \\
2.425 \mathrm{GHz}\end{array}$ & $\begin{array}{l}20 \\
2.450 \mathrm{GHz}\end{array}$ & \begin{tabular}{l}
$26.480 \mathrm{GHz}$ \\
\hline $\begin{array}{l}\text { Packet } \\
\text { loss }\end{array}$
\end{tabular} \\
\hline
\end{tabular}

The results show that the nearest is affected by quite an important packet loss that can affect the reliability of a data communications system. This implies the best trade-off between the transmission method chosen and the frequency channel used.

\section{What needs to be done to implement industrial wireless solutions?}

\subsection{The environment}

The industrial environments present some specific issues and requirements. For example, the I\&C domain concerns instrumentation, supervisory and control of the processes. I\&C focuses mainly on three levels that can be represented as below:

Table 11. Typical I\&C architecture

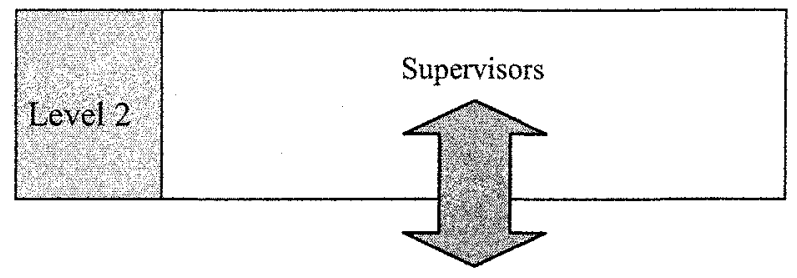




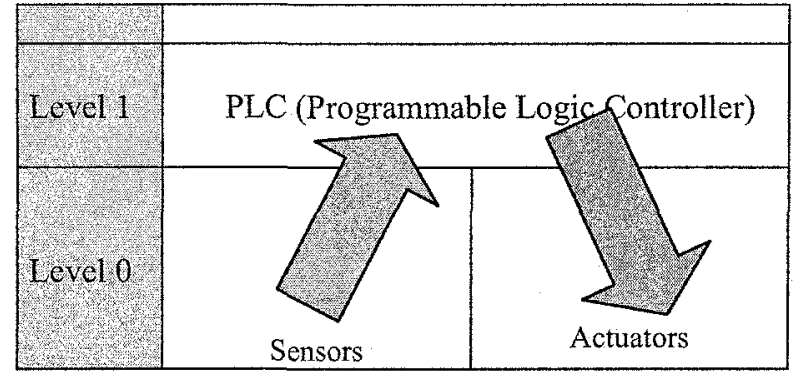

This functional architecture has several level-to-level interfaces requirements that need to be achieved by the communications network. These requirements are:

- Level 0 to level 1: real-time control (persistent stable duplex communications links), deterministic data transfer (robustness of the LLC stack), short ranges communications, always-connected, lower data rate communications.

- Level 1 to level 2: wide range communications, hybrid-type physical medium, not-always connected, higher data rate communications, possible data aggregation.

\subsection{The benefits from going wireless}

The benefits one can expect from going wireless for a sensor network in the I\&C domain can be listed:

- cables cost reduction

- mobile points of acquisition

- self-healing communications architecture

- low-power consumption

- adaptable topology (star, tree, mesh)

- ad-hoc communications

- harsh wiring conditions and difficult environment

- hand-over between WPAN cells and between WPAN and WLAN architecture (typical uses of wireless networks are shown in in the E.D.F. - Electricité De France - environment)

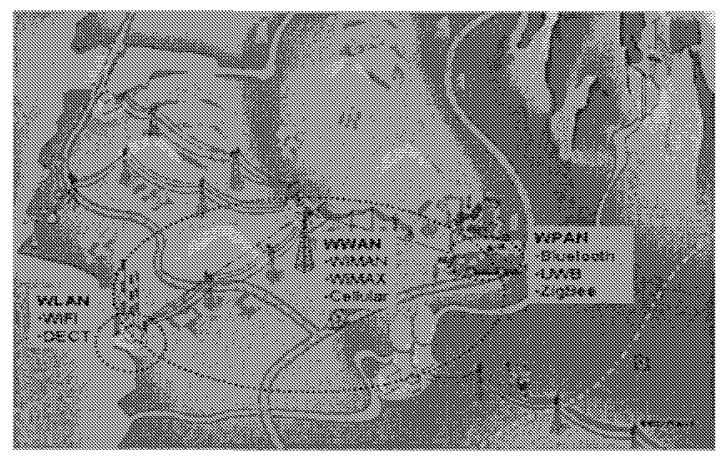

Fig. 5. Wireless technologies for utilities applications 


\subsection{What needs to be done?}

These benefits can be obtained if the following challenges are fulfilled:

- Electro-Magnetic Compatibility satisfied despite persistent EMI (Electro Magnetic Interference) from electric welding/motors, transformers, lightning, switches, ovens, mid and high-voltage lines...

- Possible interference from same-band RF devices turned on accidentally or maliciously

- Worse large scale path-loss

- Worse fading (multipart)

- Optimised radio cell distribution

- Advanced networks protocols

The following table proposes some suggested solutions and optimizations:

Table 12. Suggested solutions and optimizations

\begin{tabular}{|c|c|c|c|}
\hline & Challenges & Solutions & Optimizations \\
\hline 1 & EMI & $\begin{array}{l}\text { FHSS, retransmission, } \\
\text { UWB }\end{array}$ & $\begin{array}{l}\text { Notches, wide band } \\
\text { protocols }\end{array}$ \\
\hline 2 & $\begin{array}{l}\text { Same-band RF } \\
\text { devices }\end{array}$ & OFDM, CSMA & Random retransmission \\
\hline 3 & Path-loss & DSSS, MIMO & Multiple antennas \\
\hline 4 & Fading & $\begin{array}{l}\text { Repeaters, smart } \\
\text { antennas }\end{array}$ & Power regulations \\
\hline 5 & Radio cell & $\begin{array}{l}\text { RF expertise, hybrid } \\
\text { fixed and mobile bas } \\
\text { stations }\end{array}$ & $\begin{array}{l}\text { Radio environment } \\
\text { modeling tool }\end{array}$ \\
\hline 6 & Network protocols & $\begin{array}{l}\text { Proactive and On- } \\
\text { demand routing protocol }\end{array}$ & $\begin{array}{l}\text { Energy oriented adaptative } \\
\text { protocol, payload balance } \\
\text { between nodes }\end{array}$ \\
\hline
\end{tabular}

\section{The right solutions for the right applications}

Once we have gathered all these requirements and technical characteristics of the wireless technologies, one is ready to start designing the right solutions for the right applications. For instance, none technology is perfectly matching the needs of the applications and being aware of the bottlenecks of each one helps the network architect to deploy the optimized solution.

At E.D.F., we have different applications cases of wireless networks in an industrial environment such as:

- wireless tele-dosimetry

- mobile handheld devices for I\&C patrols 
- telecontrol of far-remote power plant sites

- geo-localization of biohazard products

The typical applications requirements in the I\&C domain can be summarized into these tables:

\subsection{Control applications}

Table 13. Controls applications Vs wireless solutions

\begin{tabular}{|c|c|c|c|}
\hline Constraints & & Range & \\
\hline Real-time & Yes & \multirow{7}{*}{\begin{tabular}{|l|l|} 
WPAN & WLAN \\
\end{tabular}} & \multirow{7}{*}{$\begin{array}{l}\text { WWAN } \\
\text { (rarely) }\end{array}$} \\
\hline Harsh RF & Yes & & \\
\hline Battery life & No & & \\
\hline Mobility & No & & \\
\hline Data rate & No & & \\
\hline Ad-hoc & No & & \\
\hline Security & Yes & & \\
\hline
\end{tabular}

\subsection{Measure applications}

Table 14. Measures applications Vs wireless solutions

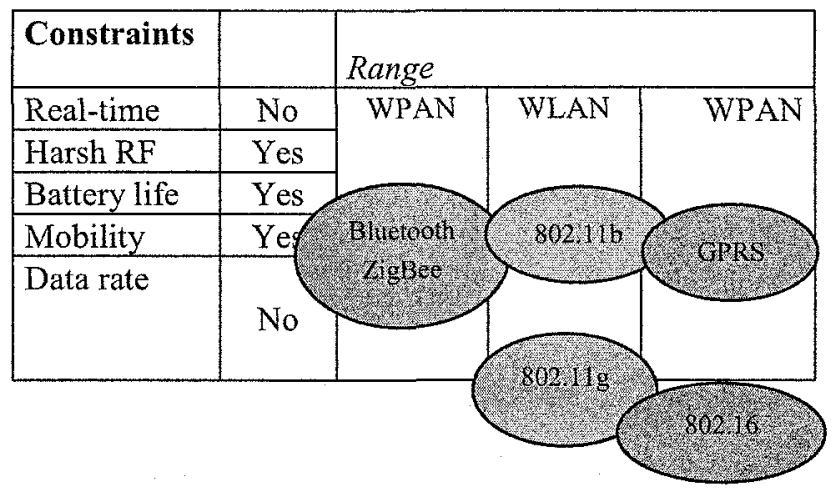




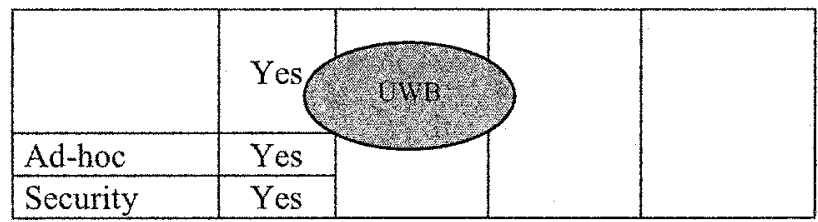

Sometimes, we are able to find complete wireless solutions for controls or measures applications. For instance, the EDF R\&D EMC laboratory specifies that wireless can interfere with old analog electronic boards.

To overcome such a barrier, we need to hybrid the technologies combining wireless and wired solutions. Concerning the wired solutions, PLC (Power Line Communications) networks can also reduce the cable cost and achieve the needed network requirements by using standardized interfaces.

\subsection{Hybrid networks: wireless and power line networks}

In the past years, PLC (Power Line Communications) technologies have reached a level of maturity in terms of data rate, standardization, inter-operability with the generalization of IEEE 802.3 standard and security.

That maturity allows its use in the industrial environments, such as power plants and sub-stations, by implementing the last developments in PLC networks.

Nowadays PLC Networks technologies can be described by several industrial standard-like:

Table 15. PLC Technologies

\begin{tabular}{|l|l|}
\hline Data rate & $P L C$ technology \\
\hline Low & X10 \\
& LonWorks \\
& CEBus \\
& Homeplug Control and Command (2006) \\
\hline High & Homeplug 1.0, AV \\
& DS2 \\
& Spidcom \\
\hline
\end{tabular}

Besides this list of PLC technologies, we don't look after using Homeplug BPL for industrial applications.

Finally, the cutting-edge industrial networks equipment could be a mix between:

- Zigbee and Homeplug Command and Control

- 802.11 and Homeplug AV

- UWB and Homeplug Command and Control

\section{Conclusion and future works}

The general feedback from our experimentation and test cases in utilities industrial environment is as follows: 
- For Process Controls applications, IEEE-802.11 family standard needs to be implemented/deployed in one hand with WIPS (Wireless Intrusion Prevention System) and WIDS (Wireless Intrusion Detection System), and in the other hand with non-beacon transmission mode to reduce latency. Moreover, interference with existing analog electronic control devices is a real issue that needs to be carefully detected before any deployment. Thus, we believe that an hybrid communication architecture combining Power Line Communication technology with the IEEE-802.11 family represents a cost-effective and interesting alternative.

- For Wireless Measures applications, WPAN technologies like Zigbee and UWB are the technologies of choice as a lot of researches have been done in the area of power consumption optimisation control routing protocol [7]. Of course, careful wireless sensor network design is particularly important in terms of power conservative performance. This is an area we continue to investigate in terms of network modelling, design and deployment engineering tools that must take into account the industrial installations characteristics.

\section{References}

[1] Institute of Electrical and Electronics Engineers. IEEE Standard Computer Dictionary: A Compilation of IEEE Standard Computer Glossaries. New York, NY: 1990.

[2] http://www.wikipedia.org/WIKL/ofdm.

[3] K. Fazel and S. Kaiser, "Multi-Carrier and Spread Spectrum Systems", Wiley Editor, 2003.

[4] J. Meel's (De Nayer Institute), "SS Introduction", October 1999.

[5] http://www.ba-loerrach.de/stzedn

[6] http://www.xbow.com/Products/Product_pdf_files/Wireless_pdf/ZigBeeandWiFiInterfere nce.pdf

[7] $\mathrm{Ya} \mathrm{Xu}$, John Hedeimann, Deborah Estrin, "Adaptive Energy-Conserving Routing for Multihop Ad hoc Networks", USC/ISI Research report 527, October 2000.

[8] J. Karedal et al, "Statistical Analysis of the UWB Channel in an Industrial Environment", IEEE Vehicular Technology Conference, pp. 81-85, December 2004

[9] M. Andersson, "IEEE 802.1 lb and Bluetooth in an Industrial Environment", connectBlue $\mathrm{AB}$, May 2001.

[10] Qixin Wang, Xue Liu, Weiqun Chen*, Wenbo He, and Marco Caccamo, Real-Time Systems Lab, CS Dept., UIUC, *ECECS, Univ. of Cincinnati "Building Robust Wireless LAN for Industrial Control with DSSS-CDMA Cellphone Network Paradigm" IEEE RTSS 2005 